\title{
Heavy Metals Inflow into Lake Muhazi, Rwanda
}

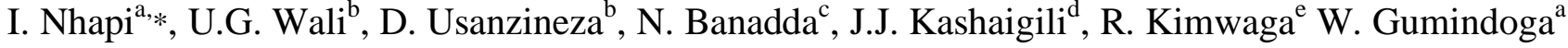 \\ and S. Sendagi ${ }^{\mathrm{c}}$
}

\author{
${ }^{a}$ Department of Civil Engineering, University of Zimbabwe, Box MP167, Mt. Pleasant, Harare, Zimbabwe \\ ${ }^{b}$ WREM Project, Faculty of Applied Science, National University of Rwanda, Box 117 Butare, Rwanda \\ ${ }^{c}$ Department of Agricultural and BioSystems Engineering, Makerere University, P.O. Box 7086, Kampala, Uganda \\ ${ }^{d}$ Faculty of Forestry and Nature Conservation, Sokoine University of Agriculture, Box 3003 Morogoro, Tanzania \\ ${ }^{e}$ Department of Water Resources Engineering, University of Dar es Salaam P. O. Box 35131, Dar es Salaam, Tanzania
}

\begin{abstract}
Most tropical African lakes are facing pollution problems due to the rapid population growth and industrialization in their riparian communities. Lake Muhazi in Rwanda is one of such lakes which has experienced a dramatic decrease in fish production since the eighties, with also reports of low water transparencies and high turbidities. The lakeshores are now being developed for ecotourism and this requires sound environmental management to make the planned activities viable. The purpose of this study was to assess heavy metal pollution in the tributary rivers of Lake Muhazi. The concentration of heavy metals in major tributaries was monitored for the period July to October 2007. The parameters studied are cadmium, chromium, copper, iron, lead, manganese, zinc, pH and temperature. Fourteen sampling stations on the Inflow Rivers and the spillway were monitored fortnightly. The samples collected for heavy metal analysis were preserved and stored in cooler boxes and analyzed in the laboratory using Standard Methods. Temperature and $\mathrm{pH}$ were measured in the field using $\mathrm{HACH}$ field testing kits. The concentration (mean \pm standard deviation) of $\mathrm{Zn}$ was found to be $0.040 \pm 0.103 \mathrm{mg} / \mathrm{L}$, Cd $0.031 \pm 0.007 \mathrm{mg} / \mathrm{L}, \mathrm{Pb} 0.487 \pm 0.452 \mathrm{mg} / \mathrm{L}, \mathrm{Fe} 7.53 \pm 13.34 \mathrm{mg} / \mathrm{L}, \mathrm{Mn} 1.01 \pm 1.31 \mathrm{mg} / \mathrm{L}$, chromium $0 \mathrm{mg} / \mathrm{L}$ and copper $0 \mathrm{mg} / \mathrm{L}$. The concentrations of measured parameters deviate much from the recommended ones thus posing serious problems to aquatic life. It has also been shown that the high metal concentration levels in Lake Muhazi are related to landuse activities in the catchment. It is thus recommended that farming practices and erosion be controlled in the catchment to contain pollutant discharges into the lake. Lead is the main anthropogenic pollutant which has been found in the watershed of Lake Muhazi.
\end{abstract}

Keywords: Heavy metal pollution, Lake water quality, Lake Muhazi, Land use, Equatorial Lakes, Rwanda.

\section{INTRODUCTION}

Water is undoubtedly the most precious natural resource that exists on planet earth. Although as humans we recognize this fact, we disregard it by polluting our rivers, lakes, oceans, etc [1]. Water pollution occurs when a body of water is adversely affected due to the addition of excess amounts of materials to the water. When it is unfit for its intended use, water is considered polluted [2]. Although some kind of water pollution does occur through natural processes, pollution is mostly attributed to anthropogenic activities.

Some heavy metals such as $\mathrm{Cr}, \mathrm{Cu}, \mathrm{Fe}$ and, $\mathrm{Zn}$ are essential for biological life in small quantities while others such as $\mathrm{Pb}$ and $\mathrm{Cd}$ do not have a vital function and could be harmful to organisms even in small concentrations [3]. Heavy metals

*Address correspondence to this author at the Department of Civil Engineering, University of Zimbabwe, Box MP167, Mt. Pleasant, Harare, Zimbabwe; Tel: +263-733414529; E-mail: i_nhapi@yahoo.com have therefore received universal public attention because of concerns that they will cause long-term damage to the environment [4].

The toxicity of a metal is usually defined in terms of the concentration required to cause an acute response (usually death) or a sub-lethal response [3]. Common sub-lethal responses of aquatic organisms to increased heavy metal concentrations include the inhibition of growth, the inhibition of settlement by marine invertebrate larvae, and the interference with reproduction, metabolism and behavior [4]. The risk of adverse effects is greatest during long-term exposure, but acute effects can occur when the concentrations rise above 310 times as high as the lowest harmful level. The primary sources of heavy metal pollution in lakes are input from rivers, sediments and the atmosphere [2]. Heavy metals enter water bodies from both natural and anthropogenic sources: atmospheric deposition, weathering of rocks, erosion, runoff, untreated sewage, agricultural activities and industries and mining [5]. 


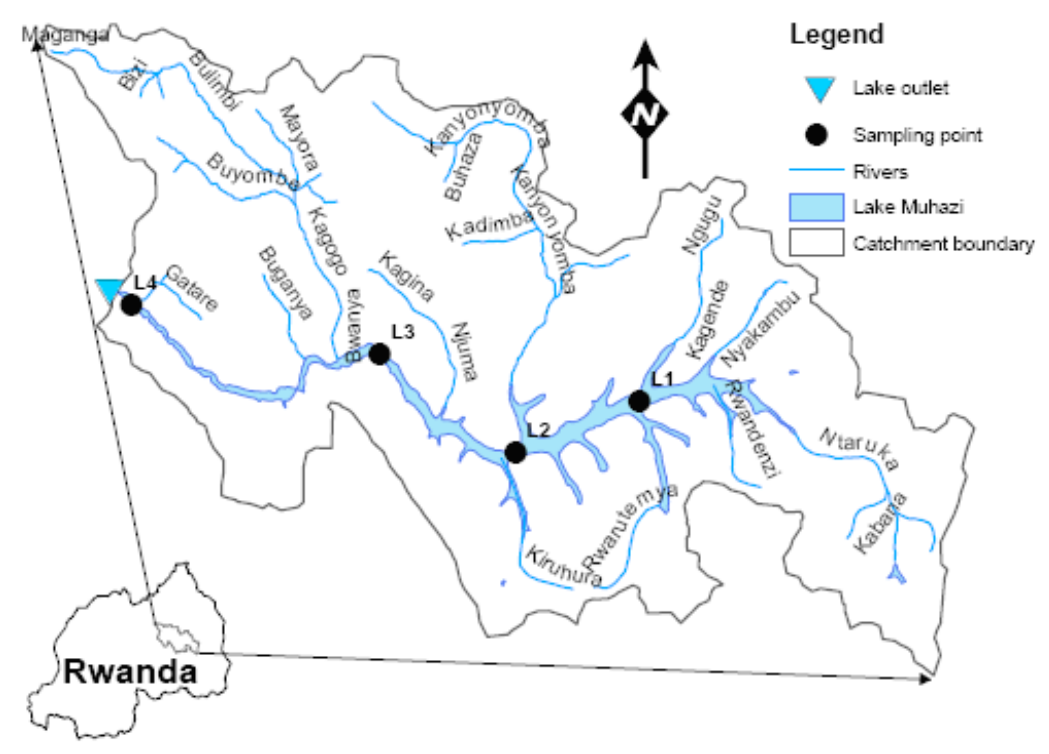

Fig. (1). Location of Lake Muhazi in Rwanda.

The water quality of Lake Muhazi in Rwanda is threatened by increased heavy metal loading from different sources but most notably from the inflowing water. While that has been noted, not much is known in terms of types and quantities of heavy metal concentrations. The main objective of this study was to assess the water quality of the tributaries of Lake Muhazi, focusing on heavy metals, in order to better understand the system and make informed decisions for the sustainable management of the Lake and its surroundings.

\section{MATERIALS AND METHODS}

\subsection{Study Area}

Lake Muhazi is situated in the Eastern Province of Rwanda along the northern margin of the Rwamagana District (Fig. 1). The lake has an altitude of $1,443 \mathrm{~m}$ above mean sea level, a total catchment surface area of $829 \mathrm{~km}^{2}$, a surface area of $34.1 \mathrm{~km}^{2}$, a depth of about $14 \mathrm{~m}$ (max) and $10 \mathrm{~m}$ (average) and a volume of 330 million cubic meters. The maximum length of this lake is about $37 \mathrm{~km}$ with a mean width of $0.6 \mathrm{~km}$.

Lake Muhazi currently has a small earth dam with a concrete weir outlet at its discharge point into the Nyabugogo River. The dam was constructed in 1999 in an attempt to raise the water level in the lake and thus prevent it from drying up. The water level of the Lake was dropping considerably since the 1970s as a result of increased water demand for the irrigation of rice and sugar plantations on the outskirts of the capital city. The reduced water levels of the lake could have serious ecological impacts on the aquatic and the surrounding terrestrial environments.

The Lake is distinguished into two parts: the western part towards the lake outlet, which is located on schist rock and surrounded by steep hills and the eastern part which lies on granitic soils [6]. Lake Muhazi is characterized as a shallow lake with a rather unstable diurnal stratification and with slight differences in mixing regime between its eastern, deepest part and its western, shallowest part.

\subsection{Landcover Assessment of the Lake Muhazi Sub- Catchment}

The Land Satellite Thematic Mapper (Landsat TM 4 \& 5) imagery of 2008 was used for landcover classification of the Lake Muhazi sub-catchment. A $30 \mathrm{~m}$ resolution imagery was obtained from the website: http://glovis.usgs.gov. The imagery was first geographically referenced to facilitate its analysis and was also co-registered to the other ancillary data, i.e. the topographic maps of Lake Muhazi area as well as the area's Digital Elevation Model (DEM). Supervised classification using maximum likelihood dichotomized the Lake Muhazi area into 6 main classes viz: Forest, Grassland, Water bodies and marshy, Agriculture, and Mosaic vegetation (forest, grassland, shrub and cropland). Maximum likelihood classification was chosen because it assumes that the statistics for each class in each band are normally distributed and calculates the probability that a given pixel belongs to a specific class [7]. Each pixel is assigned to the class that has the highest probability (that is, the maximum likelihood). If the highest probability is smaller than a specified threshold, then the pixel remains unclassified [8]. Ground control points taken in 2007 were used as the training sample set. This was done with cross reference from the $350 \mathrm{~m}$ resolution ESA GlobCover map of 2009 [9], derived from the Medium Resolution Imaging Spectrometer (MERIS). Other supporting information was obtained from topographic maps and Google images of the study area. The sample set was created using the TM band processing color composite $\mathrm{R} / \mathrm{G} / \mathrm{B}: 5,4,3$ for visual interpretation. Band 3 represents visible electromagnetic radiation with wavelengths $0.63-$ $0.69 \mu \mathrm{m}$, respectively. Band 4 represents near infrared with wavelengths of $0.76-0.90 \mu \mathrm{m}$, and bands 5 represent midinfrared with wavelengths of 1.55-1.75.

\subsection{Water Sample Collection and Analysis}

The concentration of heavy metals in major tributaries was monitored for the period July to October 2007. Samples were collected approximately every two weeks from 12 sites 


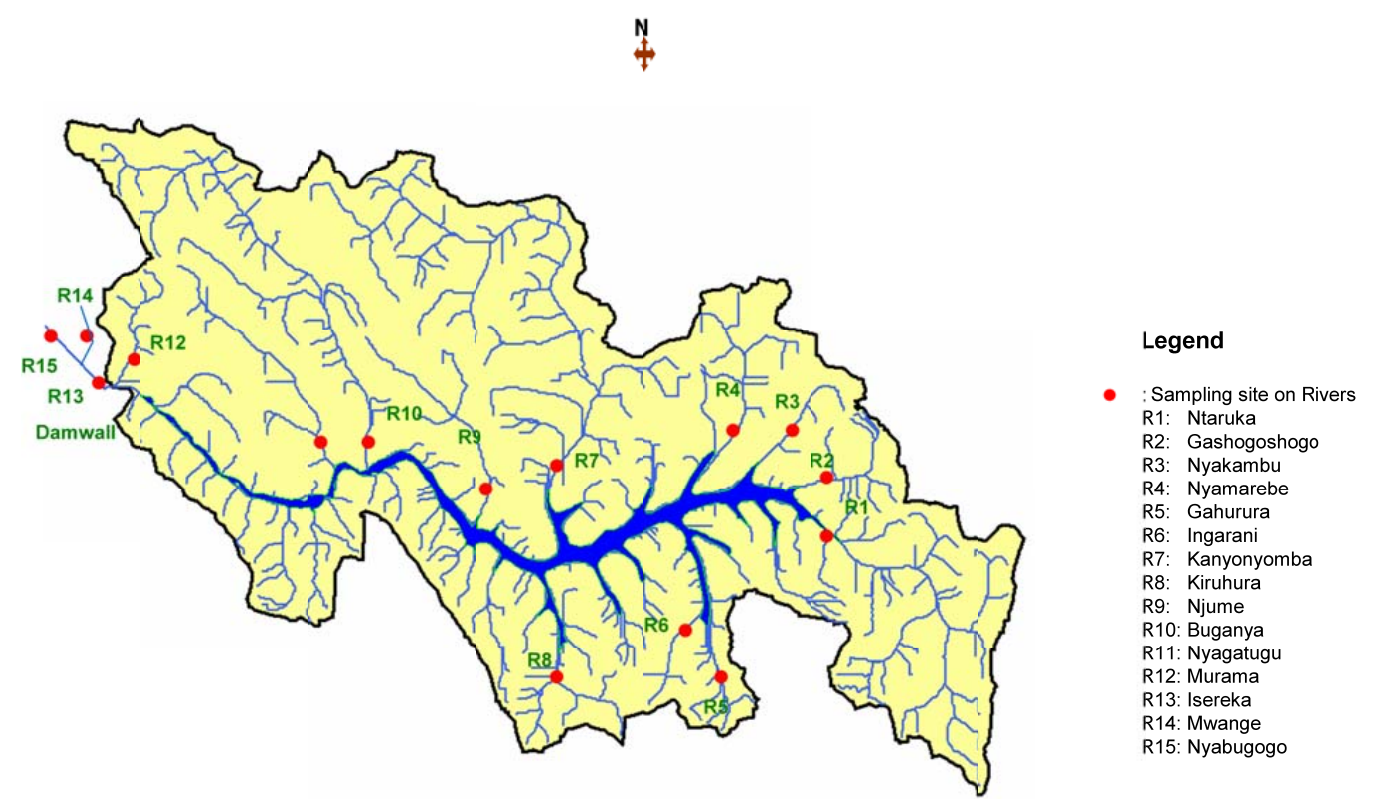

Fig. (2). Location of sampling sites around Lake Muhazi for points monitored July-Oct'07.

on the major rivers that feed into Lake Muhazi, one site located on the Lake spillway, and two points downstream of the spillway. The sampling sites are shown in Fig. (2) and attempted to cover as many tributaries as practicable. The water samples were preserved and stored in $560 \mathrm{ml}$ plastic bottles and placed in cooler boxes stuffed with ice. After thorough cleaning, the sampling bottles were rinsed and left to stand in 1M HCL until reaching the sampling site where they were rinsed thrice with sample water before final collection. The water temperature and $\mathrm{pH}$ were measured in the field using portable HACH meters. A GPS (Garmin Etrex Vista $\mathrm{H}$ type) was used to mark and identify the sampling sites. Water samples from the rivers were taken approximately in the middle of the river using a sampling stick. The average river width was about $2 \mathrm{~m}$.

Samples were analyzed for heavy metals using standard procedures. The water samples for the analysis of total metal concentration $(\mathrm{Cd}, \mathrm{Cr}, \mathrm{Cu}, \mathrm{Fe}, \mathrm{Mn}, \mathrm{Pb}$, and $\mathrm{Zn})$ were digested with nitric acid without any filtration. The actual concentrations of metals were determined using an Atomic Absorption Spectrophotometer (Perkin Elmer type). It is noted that the detection limit of heavy metals for this equipment is $0.001 \mathrm{mg} / \mathrm{L}$, and results in this paper are therefore presented to three decimal places.

\subsection{Data Analysis and Presentation}

To describe the basic features of data in this study, descriptive statistics have been used. Microsoft Excel Software and SPSS Software have been used to analyze data in terms of mean, median and standard deviation. The median was used to express the middle value in a dataset since the median is less sensitive to outliers (extreme scores) than the mean and thus a better measure than the mean for skewed distributions (skewness measures the symmetry of a distribution). A symmetric distribution is most common, and is not skewed. If the distribution is not symmetric, and one side does not reflect the other, then it is skewed. The mean was used as the average value of a dataset. The mean is a good measure of central tendency for symmetrical distributions but could be misleading in skewed (unbalanced, lopsided) distributions since it is influenced by outliers. In general, the mean is larger than the median in positively skewed (rightskewed) distributions and less than the median in negatively skewed (left-skewed) distributions. For the comparison of the difference between means, a one-way analysis of variance test has been used.

\section{RESULTS AND DISCUSSION}

\subsection{Landuse/landcover Assessment of Lake Muhazi sub- catchment}

Fig. (3) shows the result of digital landcover classification. Table 1 also shows that most of the area (39\%) is covered by Mosaic vegetation consisting of forest, grassland, shrub and cropland, 26\% is under Agriculture, and 20\% is covered by settlement and artificial surfaces Forest patches were also observed on the shores of Lake Muhazi (Fig. 3).

\subsection{Physical Characteristics of Tributary Rivers of Lake Muhazi}

\subsubsection{Temperature}

The average temperature measured in various rivers for three sampling periods done on: $1^{\text {st }}$ August, $26^{\text {th }}$ August and $19^{\text {th }}$ September 2007, are summarized in Fig. (4). The temperature of water could not reasonably be compared between the various inflow rivers because of different times of taking measurements for each inflow river during the day. However, it is noted that $\mathrm{R} 8$ presents the lowest average temperature $\left(19.5^{\circ} \mathrm{C}\right)$ and the dominant landuse in this area is agricultural and mosaic vegetation. The highest average is at $\mathrm{R} 9$ with $24.2^{\circ} \mathrm{C}$ which is in an area dominated settlement and artificial surfaces. 


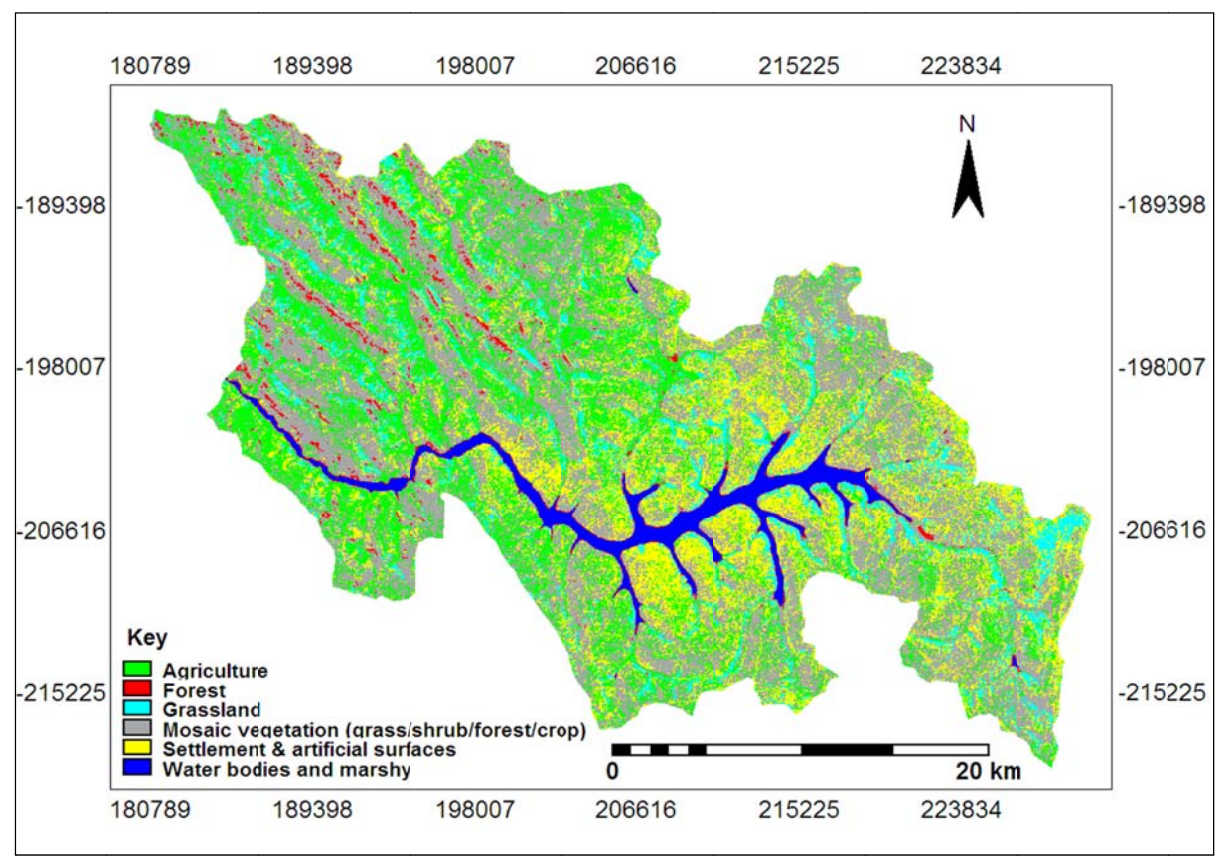

Fig. (3). Landuse/landcover of Lake Muhazi sub-catchment.

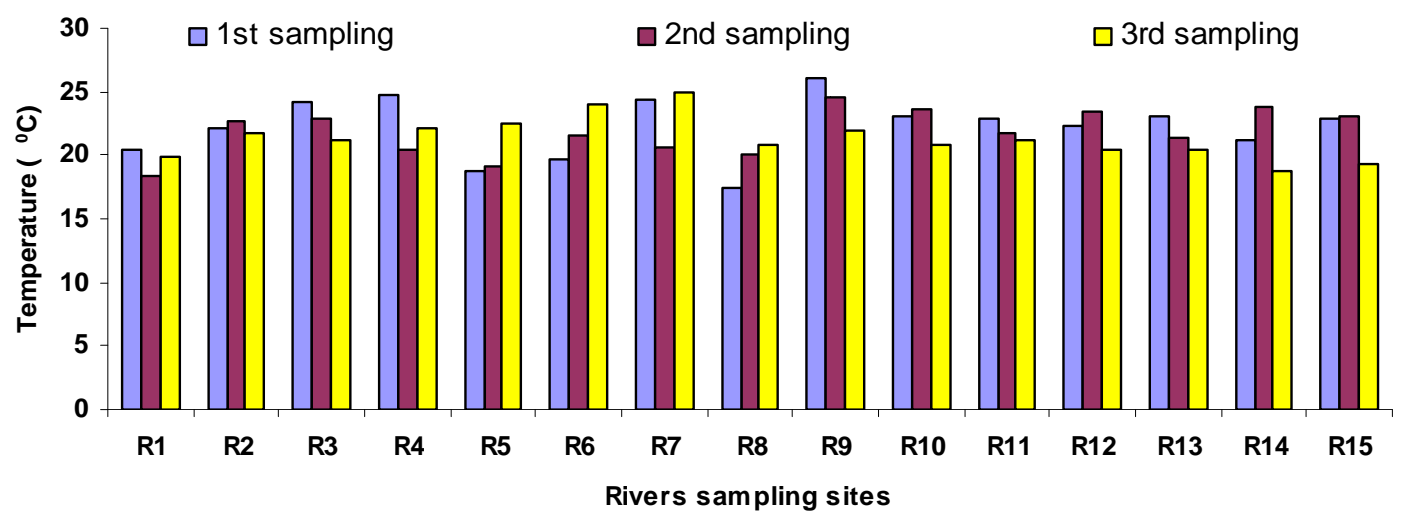

Fig. (4). Temperature values in water of the inflow rivers of Lake Muhazi, July- Oct '07.

Table 1. Distribution of Land Use Type

\begin{tabular}{|c|c|c|}
\hline Land Use/Cover Type & Area $\left(\mathbf{k m}^{2}\right)$ & Area (\%) \\
\hline \hline Agriculture & 228.1 & 26.1 \\
\hline Forest & 15.1 & 1.7 \\
\hline Grassland & 80.0 & 9.2 \\
\hline $\begin{array}{c}\text { Mosaic vegetation } \\
\text { (grass/shrub/forest/crop) }\end{array}$ & 342.0 & 39.1 \\
\hline Settlement \& artificial surfaces & 177.9 & 20.3 \\
\hline Water bodies and marshy & 31.5 & 3.6 \\
\hline TOTAL & 874.7 & 100 \\
\hline
\end{tabular}

\subsection{2. $\mathrm{pH}$}

The average values for $\mathrm{pH}$, measured in various rivers for three sampling periods are summarized in Fig. (5). The $\mathrm{pH}$ values remained relatively constant in the tributary rivers, ranging between 6.0 and 7.6 with the lowest and highest $\mathrm{pH}$ values at $\mathrm{R} 6$ and $\mathrm{R} 3$, respectively. The $\mathrm{pH}$ values are within the acceptable range of 6.5 to 9.0 given by [10] as guideline for the protection of aquatic life.

\subsection{Heavy metal concentration in tributary rivers of Lake Muhazi}

Seven heavy metals were monitored in river water samples at various sampling points. These are cadmium, chromium, copper, iron, manganese, lead and zinc. Five metals, i.e. cadmium, iron, manganese, lead and zinc were detected at all sampling sites. Copper was detected in the water samples of R2 and R5 points only, while chromium was detected at R14 point only. Table 2 shows the distribution of heavy metals found in the inflow rives of Lake Muhazi. The mean values for each metal at each site were compared with guideline values as shown in Table 2 . Pollutant concentration was measured in $\mathrm{mg} / \mathrm{L}$ and these results aggregate findings for all 


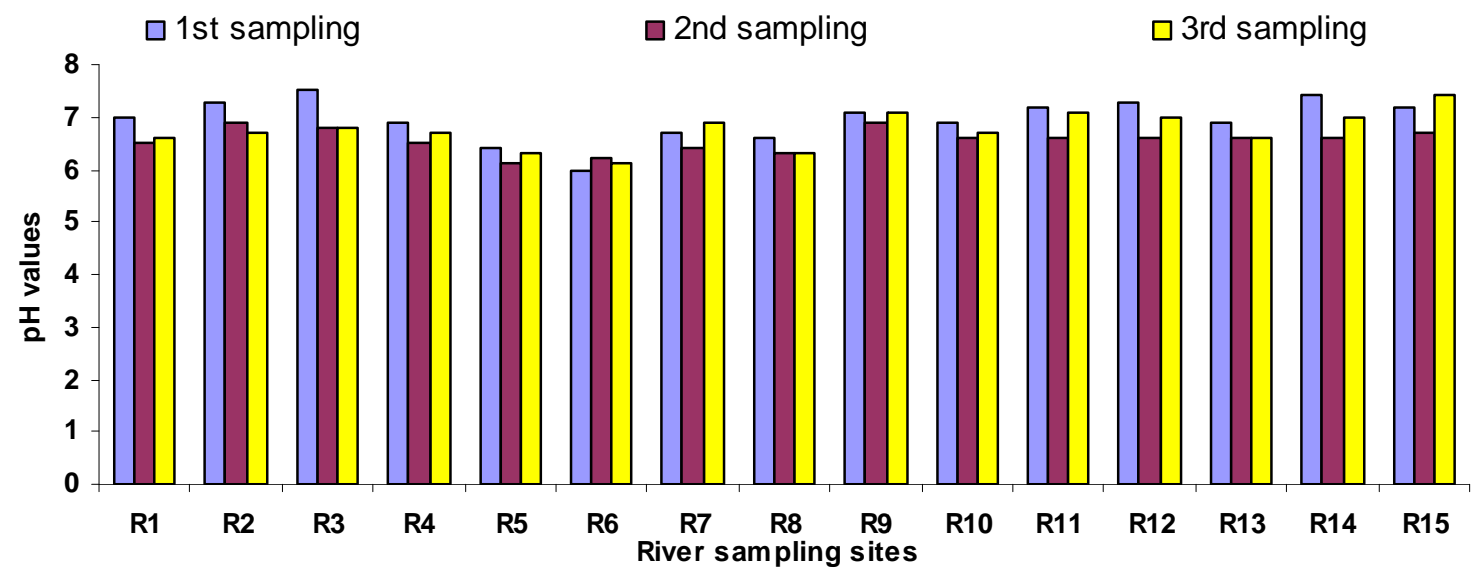

Fig. (5). pH values in water of inflow rivers of Lake Muhazi, July-Oct '07.

Table 2. Descriptive Statistics of Heavy Metal Concentrations in Tributary Rivers of Lake Muhazi and Comparison of Mean of Measured Water Quality Parameters with Standard Guidelines

\begin{tabular}{|c|c|c|c|c|c|c|c|c|c|}
\hline \multirow{2}{*}{$\begin{array}{l}\text { Heavy } \\
\text { Metal }\end{array}$} & \multirow{2}{*}{$\begin{array}{c}\text { No. of } \\
\text { Samples, N }\end{array}$} & \multirow{2}{*}{$\begin{array}{l}\text { Min. } \\
\text { Conc. } \\
\text { (mg/L) }\end{array}$} & \multirow{2}{*}{$\begin{array}{l}\text { Max. } \\
\text { Conc. } \\
(\mathrm{mg} / \mathrm{L})\end{array}$} & \multirow{2}{*}{$\begin{array}{c}\text { Mean } \\
\text { Conc } \\
(\mathrm{mg} / \mathrm{L})\end{array}$} & \multirow[t]{2}{*}{ Std. Dev. } & \multirow{2}{*}{$\begin{array}{c}\begin{array}{c}\text { WHO } \\
\text { Guideline }\end{array} \\
\text { Drinking } \\
\text { Water [11] }\end{array}$} & \multirow{2}{*}{$\begin{array}{c}\begin{array}{c}\text { Aquatic Life } \\
\text { Limit [10] }\end{array} \\
\text { Fresh Water }\end{array}$} & \multicolumn{2}{|c|}{ Agricultural Water Uses Limit [10] } \\
\hline & & & & & & & & Irrigation Water & $\begin{array}{c}\text { Livestock } \\
\text { Water }\end{array}$ \\
\hline $\mathrm{Zn}$ & 45 & 0 & 0.662 & 0.040 & 0.103 & 3.0 & 0.03 & $\begin{array}{l}1 \text { when soil } \mathrm{pH}<6.5- \\
5 \text { when soil } \mathrm{pH}>6.5\end{array}$ & 50 \\
\hline $\mathrm{Pb}$ & 45 & 0.001 & 1.622 & 0.487 & 0.452 & 0.01 & $0.001-0.007$ & 0.2 & 0.1 \\
\hline $\mathrm{Cd}$ & 45 & 0.017 & 0.045 & 0.031 & 0.007 & 0.003 & $1.7 .10^{-05}$ & 0.0051 & 0.08 \\
\hline $\mathrm{Fe}$ & 45 & 0 & 58.360 & 7.531 & 13.339 & 2.0 & 0.3 & 5 & ND* \\
\hline $\mathrm{Mn}$ & 45 & 0.003 & 5.547 & 1.006 & 1.311 & 0.4 & ND* & 0.2 & ND* \\
\hline $\mathrm{Cr}$ & 45 & 0 & 0.005 & 0 & 0.001 & 0.05 & $\mathrm{ND}^{*}$ & ND & ND* \\
\hline $\mathrm{Cu}$ & 45 & 0 & 0.006 & 0 & 0.001 & 2.0 & $0.002-0.004$ & $0.2-1$ & $0.5-5$ \\
\hline
\end{tabular}

*ND: Not defined

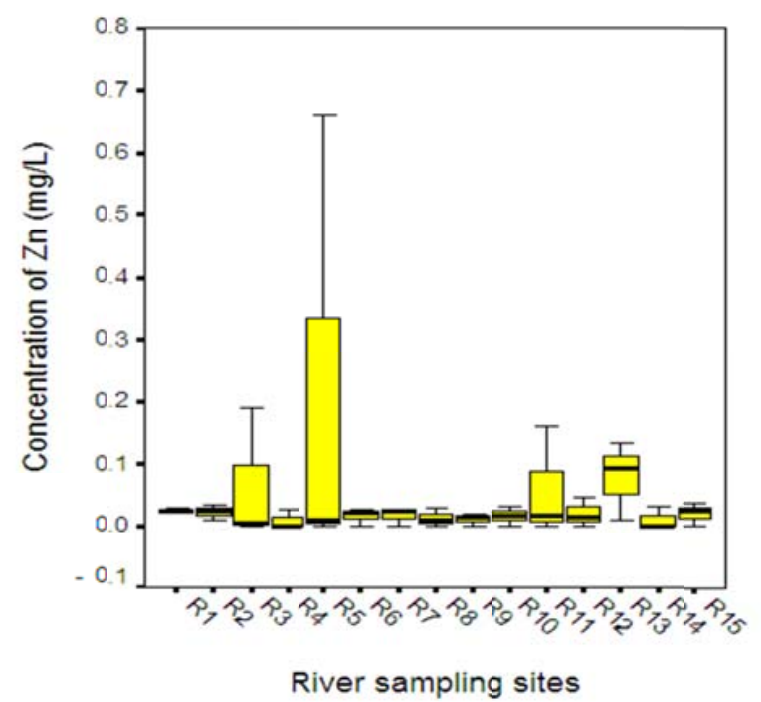

Fig. (6). Analysis results for $\mathrm{Zn}$ in inflow rivers of Lake Muhazi, July-Oct'07. sampling points. The levels of each parameter over the entire sampling points are described and discussed in the next paragraphs.

In terms of compliance with chosen standards, the results show that most of the standard guidelines are generally exceeded, especially the Canadian Water Quality Guideline for the protection of aquatic life. This means that the water in Lake Muhazi poses a risk to aquatic life and could explain why activities like fish production have gone down over the years.

\subsubsection{Zinc Concentrations}

The Fig. (6) shows the analysis results for $\mathrm{Zn}$ concentrations in inflow rivers of Lake Muhazi. The results show the median values and the variability of samples within rivers and between rivers.

From Fig. (6), points R1, R2, R6, R7 and R15 rivers samples appear to have similar medians concentrations $(0.022 \mathrm{mg} / \mathrm{L}, 0.024 \mathrm{mg} / \mathrm{L}, 0.021 \mathrm{mg} / \mathrm{L}, 0.024 \mathrm{mg} / \mathrm{L}$ and $0.024 \mathrm{mg} / \mathrm{L}$ respectively), which exceed those of points $\mathrm{R} 4$ and R14 (0 mg/L). Points R9 and R12 have similar medians 

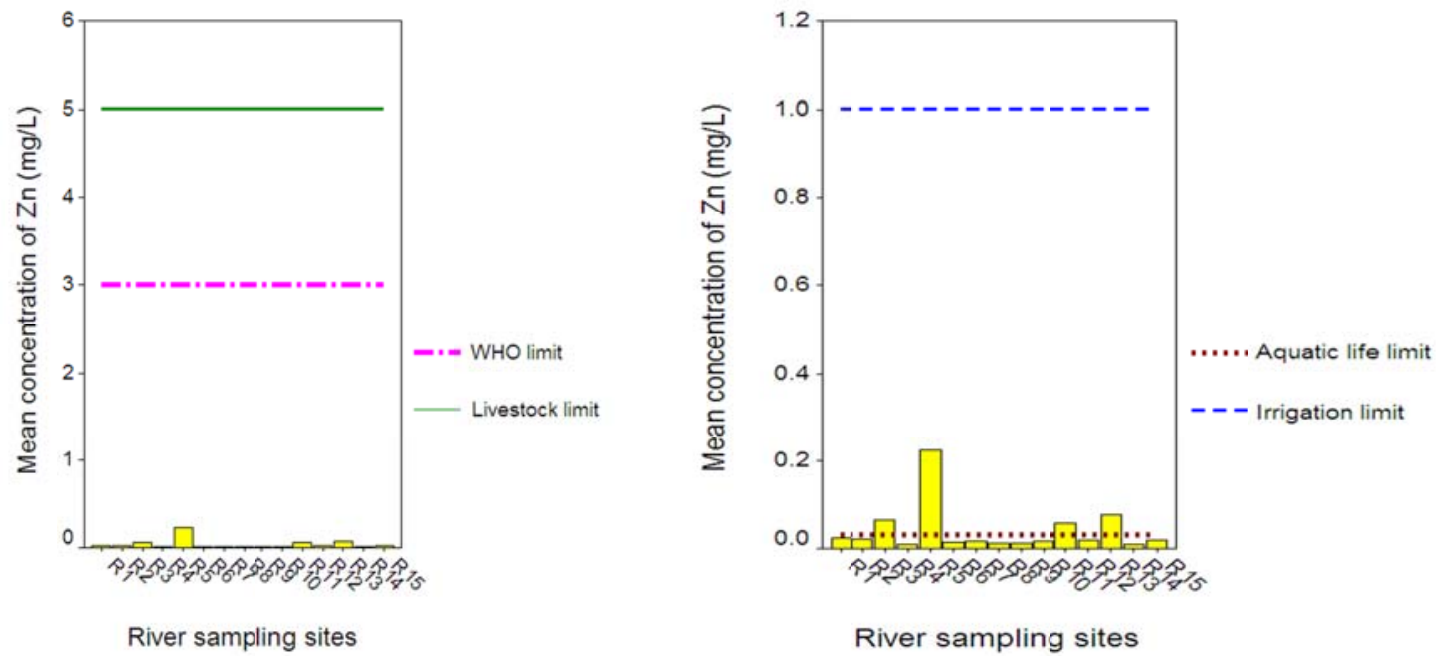

Fig. (7). Comparison of concentration of $\mathrm{Zn}$ in inflow rivers of Lake Muhazi with water quality guideline.

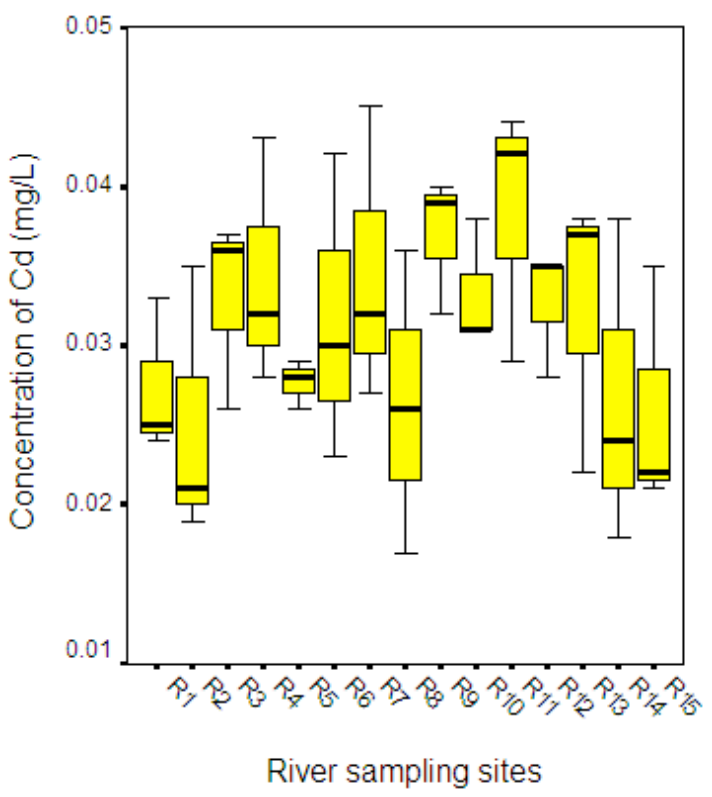

Fig. (8). Analysis results for $\mathrm{Cd}$ in inflow rivers of Lake Muhazi, July-Oct'07.

(0.014 mg/L). Points R5 and R8 had similar median concentrations $(0.010 \mathrm{mg} / \mathrm{L})$, whilst also R10 and R11 appear to have similar medians concentrations $(0.016 \mathrm{mg} / \mathrm{L}$ and 0.015 $\mathrm{mg} / \mathrm{L})$. Points R5 appeared to have larger variability than the other rivers samples. The highest value observed was 0.700 $\mathrm{mg} / \mathrm{L}$ at point R5. Point R13 was found to have the highest median $(0.093 \mathrm{mg} / \mathrm{L})$. There were no obvious outliers in any of the rivers sampled. Points R1, R2, R8, R9, R10, and R15 samples seemed to be reasonably symmetric.

The mean concentrations of $\mathrm{Zn}$ varied between 0.009 $\mathrm{mg} / \mathrm{L}$ and $0.224 \mathrm{mg} / \mathrm{L}$ with the highest at point R5 and the lowest at point $\mathrm{R} 4$. The mean values of $\mathrm{Zn}$ were higher than the Canadian Water Quality Guideline for the protection of aquatic life at points R3, R5, R11 and R13. The Canadian Water Quality Guideline for agricultural uses and WHO Drinking Water Guidelines [11] were not exceeded at any site as shown by Fig. (7).

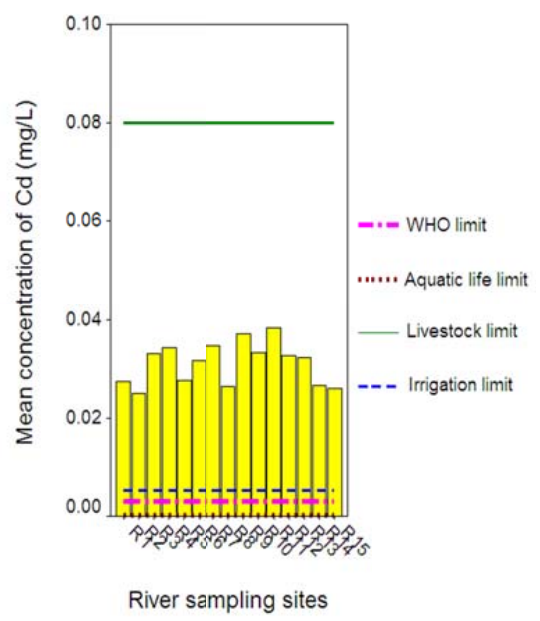

Fig. (9). Comparison of concentration of $\mathrm{Cd}$ in inflow rivers of Lake Muhazi with water quality guideline.

\subsubsection{Cadmium Concentrations}

Fig. (8) shows the variation of $\mathrm{Cd}$ concentrations in the monitored rivers. It shows that all rivers samples are asymmetric except R8 which seems to be symmetric. Points R3, R9, R11 and R13 samples were skewed to the left with 0.036 $\mathrm{mg} / \mathrm{L}, 0.039 \mathrm{mg} / \mathrm{L}, 0.042 \mathrm{mg} / \mathrm{L}$ and $0.037 \mathrm{mg} / \mathrm{L}$ respectively as medians. Points R1, R2 and R15 are skewed to the right. Points R4, R7 and R10 samples seemed to have similar medians $(0.032 \mathrm{mg} / \mathrm{L}$ for R4 and R7 and $0.032 \mathrm{mg} / \mathrm{L}$ for R10). Points R2 and R15 also have similar median concentrations $(0.021 \mathrm{mg} / \mathrm{L}$ and $0.022 \mathrm{mg} / \mathrm{L}$ respectively). The highest median is observed at R11 (0.042 mg/L) and the lowest at R2 $(0.021 \mathrm{mg} / \mathrm{L})$.

The means concentrations of $\mathrm{Cd}$ varied between 0.025 $\mathrm{mg} / \mathrm{L}$ and $0.038 \mathrm{mg} / \mathrm{L}$ with the highest at the point $\mathrm{R} 11$ and the lowest at the point R2. The mean concentrations values of $\mathrm{Cd}$ in all rivers were higher than WHO Drinking Water Quality Guidelines values and the Canadian Surface Water Quality Guidelines values except guidelines for livestock watering which were not exceeded at all sites as shown in Fig. (9). 


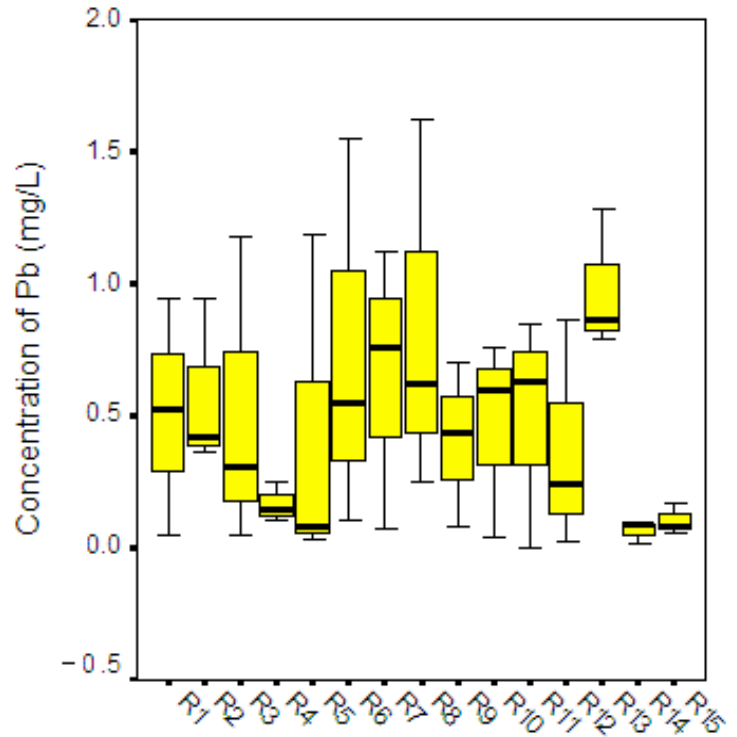

River sampling sites

Fig. (10). Analysis results for $\mathrm{Pb}$ in the inflow rivers of Lake Muhazi, July-Oct'07.

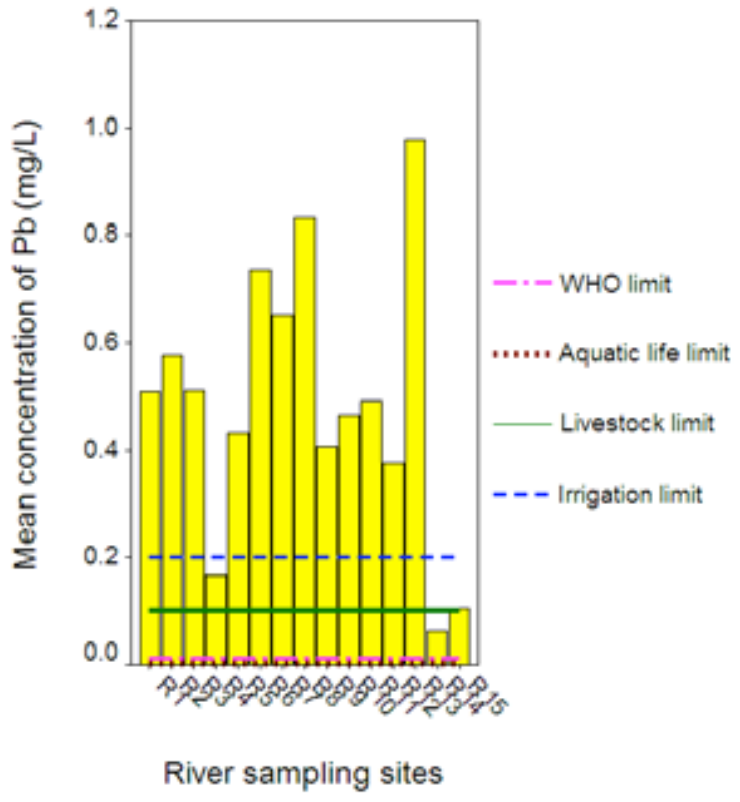

Fig. (11). Comparison of concentrations of $\mathrm{Pb}$ in the inflow rivers of Lake Muhazi with water quality guideline.

\subsubsection{Lead Concentrations}

Fig. (10) shows the variation of $\mathrm{Pb}$ concentrations in inflow rivers of Lake Muhazi. Fig. (10) shows that points R6 and R8 appear to have larger variability than the other points. Points R1 and R9 are reasonably symmetric, but points R2, R3, R5 and R13 are skewed to the right. Points $\mathrm{R} 7, \mathrm{R} 10$ and R11 are skewed to the left. There were no obvious outliers in any of the samples. Points R5, R14 and R15 seemed to have similar median concentrations with 0.080 $\mathrm{mg} / \mathrm{L}, 0,085 \mathrm{mg} / \mathrm{L}$ and $0.083 \mathrm{mg} / \mathrm{L}$ respectively. Point $\mathrm{R} 13$ has the highest median concentration and the lowest $(0.080$ $\mathrm{mg} / \mathrm{L}$ ) was observed at point R5.

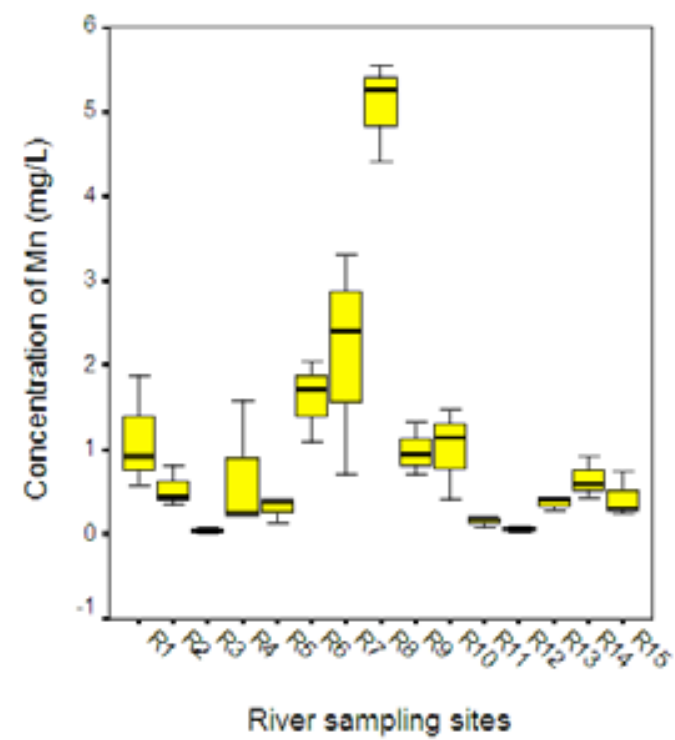

Fig. (12). Analysis results for $\mathrm{Mn}$ in the inflow rivers of Lake Muhazi, July-Oct'07.

The mean concentrations of $\mathrm{Pb}$ varied between 0.062 $\mathrm{mg} / \mathrm{L}$ and $0.978 \mathrm{mg} / \mathrm{L}$ with the highest at point R13 (outlet river) and the lowest at point R14. The occurrence of the highest figure at the Lake outlet requires further investigation as the concentration is not related to the landuse. The area is predominantly by agricultural, forest and mosaic vegetation. The mean concentrations values of $\mathrm{Pb}$ in all rivers were higher than the Canadian Water Quality Guideline for the protection of aquatic life and WHO Drinking Water Quality Guidelines values. Only points R14 and R15 had mean concentrations of, $0.062 \mathrm{mg} / \mathrm{L}$ and $0.104 \mathrm{mg} / \mathrm{L}$ respectively, which do not exceed the Canadian Water Quality Guideline for agriculture use. Point R4 also had a mean concentration value which does not exceed the irrigation guideline value as shown in Fig. (11).

\subsubsection{Manganese concentrations}

Fig. (12) shows the variation of Mn concentrations in the inflow rivers of Lake Muhazi.

Fig. (12) shows that points R7 had a large variability than other river samples. Point R8 had the highest median concentration. Points R1, R2, R4, R14 and R15 were found to be skewed to the right while points R5, R6 and R9 were skewed to the left. Points R1 and R9 seemed to have similar median concentrations with $0.928 \mathrm{mg} / \mathrm{L}$ and $0.936 \mathrm{mg} / \mathrm{L}$ respectively, as was the case for R3 $(0.050 \mathrm{mg} / \mathrm{L})$ and R12 $(0.056$ $\mathrm{mg} / \mathrm{L})$. Points R5 and R13 also seemed to have similar median concentrations $(0.400 \mathrm{mg} / \mathrm{L}$ and $0.417 \mathrm{mg} / \mathrm{L}$, respectively).

The mean concentrations of $\mathrm{Mn}$ varied between 0.042 $\mathrm{mg} / \mathrm{L}$ and $5.065 \mathrm{mg} / \mathrm{L}$ with the highest at point $\mathrm{R} 8$ and the lowest at point R3. The mean concentrations values of $\mathrm{Mn}$ were higher than the WHO Drinking Water Quality Guideline value at points R1, R2, R4, R6, R7, R8, R9, R10 and $\mathrm{R} 14$. The irrigation guideline value was also exceeded at those sites cited before and at R5, R13 and R15 as shown in Fig. (13). 


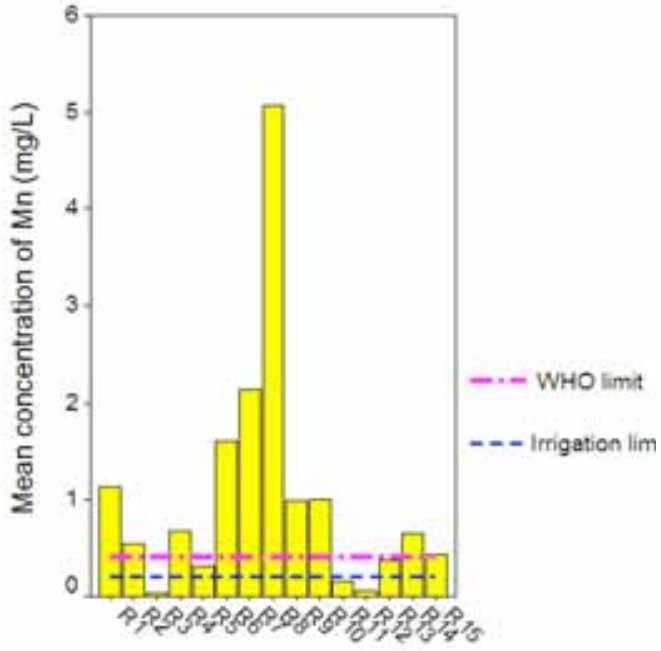

River sampling sites

Fig. (13). Comparison of concentration of $\mathrm{Mn}$ in the inflow rivers of Lake Muhazi with water quality guidelines.

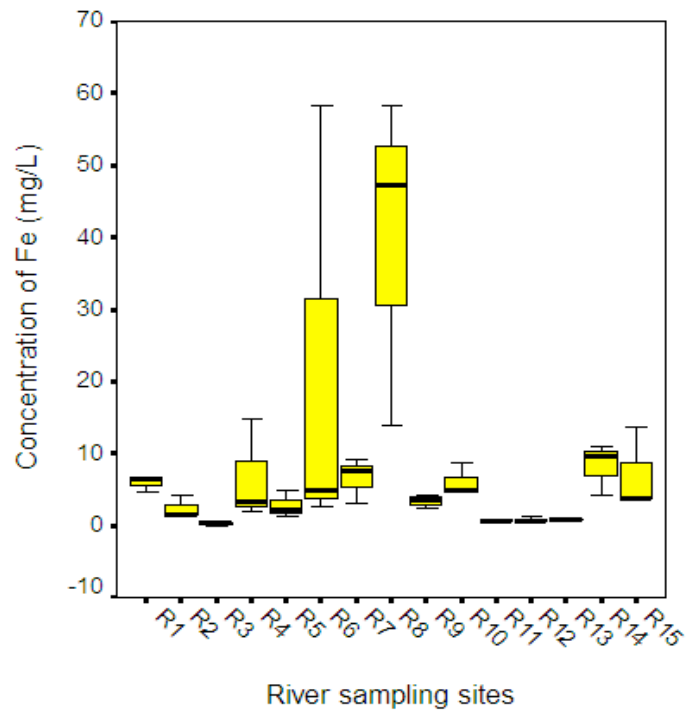

Fig. (14). Analysis results for $\mathrm{Fe}$ in the inflow rivers of Lake Muhazi, July-Oct'07.

\subsubsection{Iron Concentrations}

Fig. (14) shows the variation of Fe concentrations in the inflow rivers of Lake Muhazi. It shows that points R6 and R8 had large variability than other points. Points R4 and R6 were skewed to the right. The highest median concentration is observed at $\mathrm{R} 8(47.150 \mathrm{mg} / \mathrm{L})$ and the lowest is observed at R3 (0.364 mg/L). Points R6 and R10 seemed to have similar median concentrations (4.941 $\mathrm{mg} / \mathrm{L}$ and $4.803 \mathrm{mg} / \mathrm{L})$.

The mean concentrations of $\mathrm{Fe}$ varied between 0.300 $\mathrm{mg} / \mathrm{L}$ and $39.765 \mathrm{mg} / \mathrm{L}$ with the highest at point R8 and the lowest at point $\mathrm{R} 3$. The high concentration of $\mathrm{Fe}$ at point $\mathrm{R} 8$ is probably due to the contamination of water from an iron mine at Mununu. The mean concentration values of Fe were higher than the Canadian Water Quality Guideline for the protection of aquatic life except at R3 (0.300 mg/L) and WHO Drinking Water Quality Guideline value was not exceed at points R3, R11, R12 and R13. Guidelines for irriga-

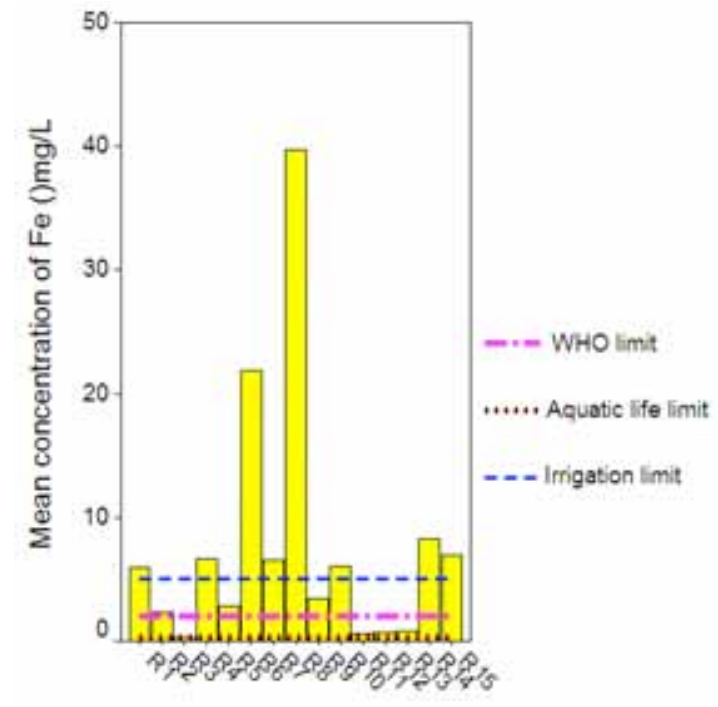

River sampling sites

Fig. (15). Comparison of concentration of $\mathrm{Fe}$ in inflow rivers of Lake Muhazi with water quality guideline.

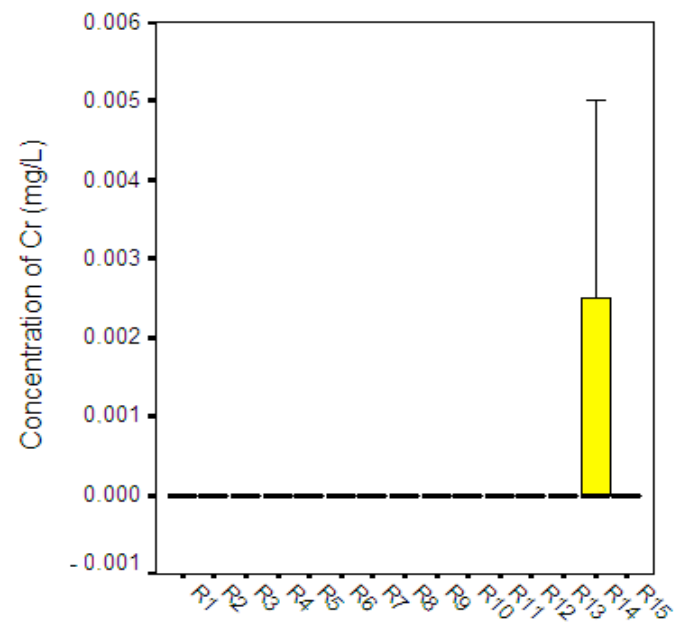

River sampling sites

Fig. (16). Analysis results for $\mathrm{Cr}$ in inflow rivers of Lake Muhazi, July-Oct'07.

tion were exceeded at R1, R4, R6, R7, R8, R10, R14 and R15 as shown in Fig. (15).

\subsubsection{Chromium Concentrations}

Fig. (16) shows the variation of $\mathrm{Cr}$ concentrations in the inflow rivers of Lake Muhazi.

Fig. (15) shows that point R14 has a large variability and $\mathrm{Cr}$ was found at point R14 only. The median concentrations of $\mathrm{Cr}$ were zero in all rivers samples.

\subsubsection{Copper Concentrations}

Fig. (17) shows the variation of $\mathrm{Cu}$ concentrations in inflow rivers of Lake Muhazi. It shows that point R11 has a large variability than others sampling points. $\mathrm{Cu}$ was found at points R5 and R11 only. It is noted that median concentrations were zero in all rivers samples. 


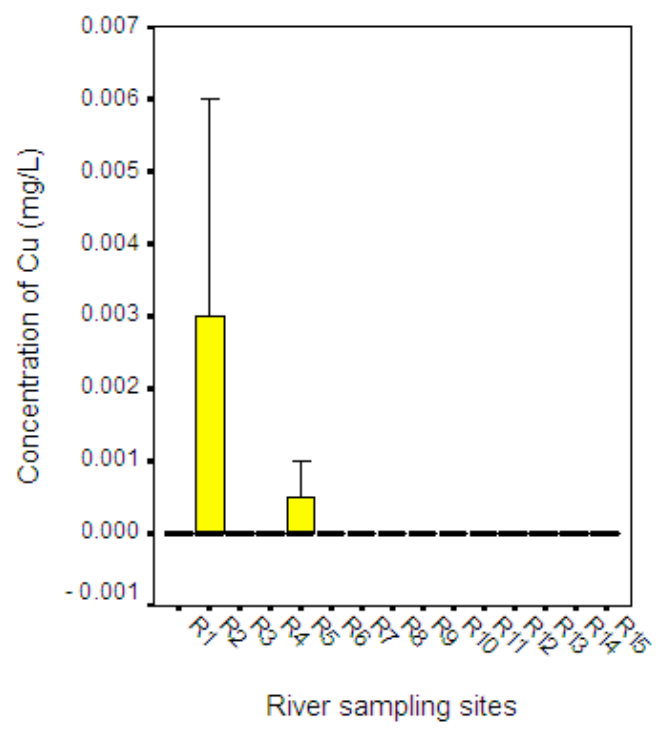

Fig. (17). Analysis results for $\mathrm{Cu}$ in inflow rivers of Lake Muhazi, July-Oct'07.

\subsection{Pollution in Relation to Landuse}

The study results suggest heavy metal pollution in the inflow Rivers of Lake Muhazi to be due to the geological nature of the rocks in the Lake Muhazi's catchment and partially due to anthropogenic activities such as use of gasoline with lead additives. Gasoline with lead additives could have partially contributed to the contamination of soils near highways/streets and in drainage ways for stormwater runoff from these areas since many of the sampled rivers are situated closer to raods. However, the extent of contamination is considered too high for this source alone and we believe that further studies are required over a longer period of time to ascertain the trend and source of lead, starting with the geological nature of the rocks in the area.

As shown by Fig. (6), point R5 had the highest mean concentration of $\mathrm{Zn}$, point R13 (the outlet river of Lake Muhazi) had the highest mean concentration of $\mathrm{Pb}$ (Fig. 10), point R10 had the highest mean concentration of Cd (Fig. 8), point R8 had the highest mean concentration of Fe (Fig. 13) and the point R7 had the highest mean concentration of $\mathrm{Mn}$ (Fig. 13). An assessment of landuse/landcover types did not fully explain the occurrence of these high figures. A further investigation on the geology of the area would aid in fully understanding the sources of these metals. However, for iron and manganese, high values are quite common in Rwanda because of the geology of the country. Mean concentrations of $\mathrm{Cr}$ and $\mathrm{Cu}$ were not detectable in almost all rivers samples.

\section{CONCLUSIONS}

1. The heavy metals in the inflow rivers of Lake Muhazi were generally higher than the recommended limits for drinking water. The concentration (mean \pm standard deviation) of $\mathrm{Zn}$ was found to be $0.040 \pm 0.103$ $\mathrm{mg} / \mathrm{L}, \mathrm{Cd} 0.031 \pm 0.007 \mathrm{mg} / \mathrm{L}, \mathrm{Pb} 0.487 \pm 0.452 \mathrm{mg} / \mathrm{L}$, Fe $7.53 \pm 13.34 \mathrm{mg} / \mathrm{L}$, Mn $1.01 \pm 1.31 \mathrm{mg} / \mathrm{L}$, chromium $0 \mathrm{mg} / \mathrm{L}$ and copper $0 \mathrm{mg} / \mathrm{L}$. Cadmium, iron, lead and manganese concentrations in the rivers were particu- larly high, but this could not be fully explained by the landuse types which are predominantly mosaic vegetation, agricultural, and settlement and artificial surfaces, in that order, in that order. It was therefore concluded that the occurrence of heavy metals in the inflow rivers of Lake Muhazi is mainly due to the geological formation of the catchment, with anthropogenic activities also playing a role.

2. There is a need to identify all controllable sources of pollution (e.g., agricultural sources; domestic sewage disposal practices, etc) throughout the watershed of Lake Muhazi and develop preventive measures to reduce heavy metal pollution. Environmental impact assessments should be done for all developmental activities around the Lake and mines should be rehabilitated after use.

\section{CONFLICT OF INTEREST}

None declared.

\section{ACKNOWLEDGEMENTS}

The authors are very grateful to Inter-University Council of Eastern Africa through Lake Victoria Research (VicRes) for accepting to pay for the publication of this work. We also thank Nuffic for sponsoring this study through the WREM Project, a collaborative capacity building project between the National University of Rwanda and the UNESCO-IHE Institute for Water Education.

\section{NOMENCLATURE}

\section{Symbols}

$\begin{array}{ll}\mathrm{Cd} & =\text { Cadmium } \\ \mathrm{Cr} & =\text { Chromium } \\ \mathrm{Cu} & =\text { Copper } \\ \mathrm{Fe} & =\text { Iron } \\ \mathrm{km} & =\text { Kilometres } \\ \mathrm{km}^{2} & =\text { Kilometres squared } \\ \mathrm{m} & =\text { Metres } \\ \mathrm{mg} / \mathrm{l} & =\text { Milligram per litre } \\ \mathrm{Mn} & =\text { Manganese } \\ \mathrm{Pb} & =\text { Lead } \\ \mathrm{Pb} & =\text { Lead } \\ \mathrm{pH} & =\text { potential of Hydrogen } \\ \mathrm{Zn} & =\text { Zinc } \\ \% & =\text { Percentage }\end{array}$

Acronyms

DEM = Digital Elevation Model

EIA $=$ Environmental Impact Assessment

GPS $=$ Global Positioning System

HCL = Hydrochloric Acid 


$$
\begin{aligned}
& \text { Max }=\text { Maximum } \\
& \text { MERIS }=\text { Medium Resolution Imaging Spectrometer } \\
& \text { VICRES }=\text { Lake Victoria Research Initiative } \\
& \text { WHO }=\text { World Health Organization } \\
& \text { WREM = Water Resources and Environmental Man- } \\
& \text { agement }
\end{aligned}
$$

\section{REFERENCES}

D. Krantz and B. Kifferstein, "Water pollution and society", University of Michigan. Available at: http://www.umich.edu/ gs265/society/water-pollution.htm, 1995.

[2] D.S. Panda, R.K. Behera, R. K. Sahu and S. N, Bandhopadhya "Heavy metal Pollution in Chilika Lake, A tropical lagoon", Orissa, India. Available at: http://ces.iisc.ernet.in, 2002.

[3] K. Squibb, "Toxicity of Metals System wide program in toxicity", University of Maryland, 2002.
[4] D. G. Smith, "Heavy Metals in the New Zealand Aquatic Environment: A Review, Water Quality Centre", Ministry of Works and Development, Wellington: New Zealand, 1986.

[5] K. Ljung, "Heavy metal discharge into Lake Victoria - A study of the Ugandan cities of Kampala, Jinja and Entebbe," MSc Thesis, Swedish University of Agricultural Sciences, Sweden, 2001.

[6] R. Mukankomeje, P-D. Plisnier, J-P. Descy and L. Massaut, "Lake Muhazi, Rwanda: limnological features and phytoplankton production," Hydrobiologia, vol. 257, pp. 107-120, 1993.

[7] L. Lucas, F. Janssen, C. Gerrit, and K. Hurneman, Principles of Remote Sensing. ITC Educational Textbooks Series; 2, $2^{\text {nd }}$ ed, 2002.

[8] J.A. Richards, “Remote Sensing Digital Image Analysis”, SpringerVerlag, Berlin 1999

[9] B. Sophie, D. Pierre, and V. Eric, "Products Description and Validation Report”, ESA, UCL, 2010

[10] Canadian Council of Ministers of the Environment (CCME), "Canadian Water Quality Guidelines" Available at: http://www.ec.gc.ca/ceqg-rcqe/English/Ceqg/Water/default.cfm, 2004.

[11] WHO (World Health Organization), "Guidelines for drinking-water quality", third edition, incorporating first addendum $\left(3^{\text {rd }} \mathrm{ed}\right)$. Available at: http://www.who.int/water_sanitation_health, 2004.

(C) Nhapi et al.; Licensee Bentham Open.

This is an open access article licensed under the terms of the Creative Commons Attribution Non-Commercial License (http://creativecommons.org/licenses/by-nc/3.0/g) which permits unrestricted, non-commercial use, distribution and reproduction in any medium, provided the work is properly cited. 